\title{
EFFECT OF COMPOST AND NUMBER OF CUTTINGS ON PRODUCTIVITY OF CORIANDRUM SATIVUM L. UNDER SINAI CONDITIONS
}

\author{
Abd El-Azim, Waleed M. \\ Department of Medicinal and Aromatic Plants, Desert Research \\ Center, El-Matareya, Cairo, Egypt \\ E-mail: dr.w_elzeary@yahoo.com
}

wo field experiments were carried out at El-Maghara
Research Station (Middle Sinai) of the Desert Research
Center (DRC), during 2014/2015 and 2015/2016 seasons, to study the effect of two doses of organic compost; 10 and 20 $\mathrm{m}^{3} /$ feddan and three cuttings frequencies (without cutting, one cutting at 45 days after sowing and two successive cutting at 45 and 60 days after sowing) on the growth and essential oil content of Coriandrum sativum L. plant grown in sandy soil. The obtained results revealed that, the best growth parameters (plant height, number of branches, weight of 1000 seeds $(\mathrm{g})$, weight of seeds per plant $(\mathrm{g})$, yield of seeds ( $\mathrm{kg} /$ feddan), oil percentage, oil yield (L/feddan), total nitrogen and carbohydrate percentages and essential oil composition were obtained by using a combination of $20 \mathrm{~m}^{3} /$ feddan compost and one cutting, after 45 days after sowing, except for plant height that showed the beast results associated with "without cutting" treatment.

Keywords: Coriandrum sativum, compost manures, cutting, essential oil, GC-mass

Coriander (Coriandrum sativum L.), a member of the family Apiaceae, is one of the important spice crops grown throughout the world. This plant has been used as a flavoring agent in food products, perfumes and cosmetics. As a medicinal plant, seeds of Coriandrum sativum have been recommended for dyspeptic complaints, convulsion, insomnia and anxiety (Emamghoreishi et al., 2005). While, the green leaves is a rich source of vitamin A. It is used in salad and gives a flavoring of soups as well as fish dishes (Singh, 1976).

The organic sources of fertilizer are helpful in increasing the availability and uptake of nutrients from the soil by plant. Compost, which is applied as organic source of fertilizer has been safe for human health and the environment. Compost can be used to improve soil structure, making soil easier to be cultivated and encouraging the root system to develop (Allison, 
1973). Several investigators revealed that, application of compost to the soil caused promoton to different growth characters and chemical constituents of Coriandrum sativum; namely Hussein et al. (2010), Moslemi et al. (2012) and Rajesh et al. (2015). Leaf cutting has been reported to increase the number of branches and umbels per plant, which in turn increase the yield of leaves and seeds in Coriandrum sativum (Tiwari et al., 2002 and Moniruzzaman and Rahman, 2015). In this study the effect of compost in two doses and number of cutting on the productivity of Coriandrum sativum has been highlighted.

\section{MATERIALS AND METHODS}

Two field experiments were carried out at El-Maghara Experimental Station of the Desert Research Center (DRC), during 2014/2015 and 2015/2016 seasons, to study the effect of two doses of organic compost (10 and $20 \mathrm{~m}^{3} /$ feddan) and three cutting frequencies (without cutting, one cutting at 45 days after sowing and two successive cuttings at 45 and 60 days after sowing) on the growth and essential oil content of Coriander plant grown in sandy soil. Physical and chemical analyses of experimental soil and irrigation water were presented in table (1). The chemical analysis of compost is presented in table (2).

Seeds were sown on soil in 15 and 18 October for the first and second seasons, respectively. In both seasons, seeds of Coriander plant were obtained from the Experimental farm of El-Maghara Station. The experimental design was split plot in three replicates with six treatments, which were the combination of two doses of compost and three cutting. The main plots were randomly devoted to organic compost treatments, while the sub-plots were assigned to number of cuttings. Plot area was $6 \mathrm{~m}^{2}$. In land preparation, compost in addition to calcium superphosphate at a rate of 32 $\mathrm{P}_{2} \mathrm{O}_{4}$ were mixed with the soil before sowing. Nitrogen and potassium fertilizers were added at the rate of 80: $24, \mathrm{~N}: \mathrm{K}_{2} \mathrm{O} \mathrm{kg} /$ feddan divided in two equal doses a recommended rate reported by Osman (2000). The first addition was after one month from sowing, while the second was applied after one month after the first. Seeds were sown $30 \mathrm{~cm}$ between hills on rows; $75 \mathrm{~cm}$ apart, thinning for two plants in hill. Experimental plots were irrigated using drip irrigation $4 \mathrm{~L} / \mathrm{h}$, day after day in two additions in the morning and afternoon. The plants were harvested in the end of season in 17 and 21 April in the two seasons. Meanwhile, plant height, number of branches, weight of 1000 seeds, weight of seeds per plant (g), yield of seeds $(\mathrm{kg} / \mathrm{feddan})$, oil percentage, oil yield (L/feddan), total nitrogen percentage and total carbohydrate percentage were recorded for each season of Coriander plant. Chemical analysis included, total carbohydrate according to Chaplin and Kennedy (1994) total nitrogen according to James (1995). The essential oil composition in some different treatments was determined using 


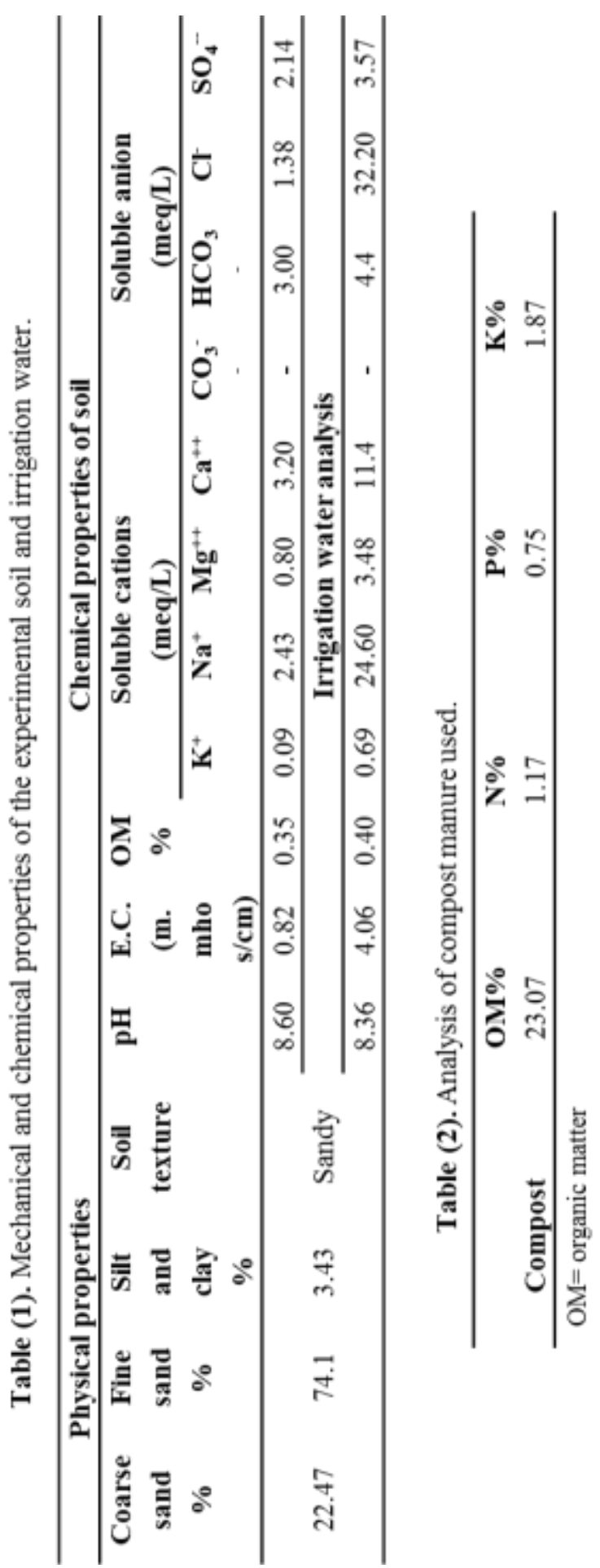

Egyptian J. Desert Res., 66, No. 1, 57-68 (2016) 


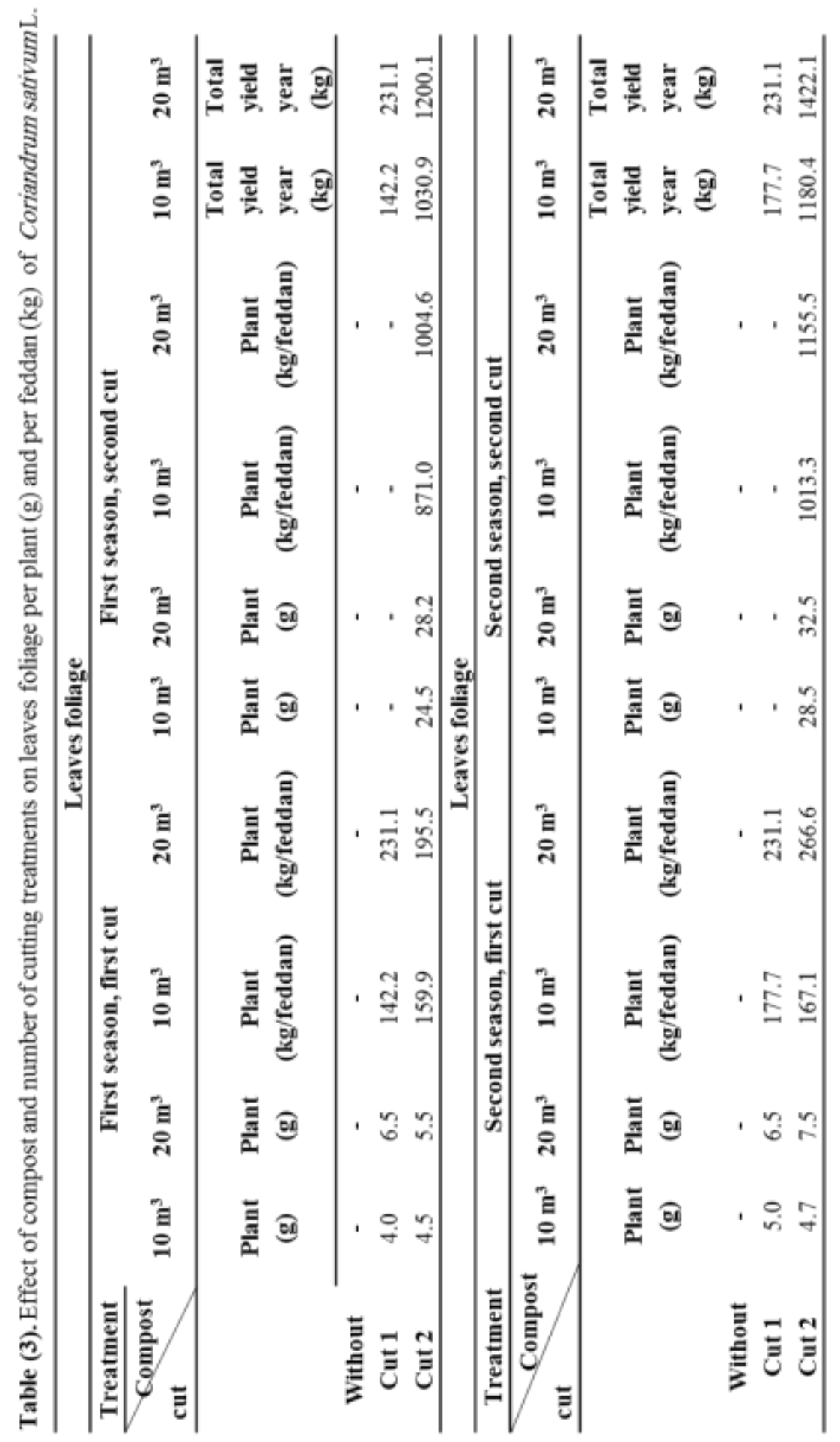

Egyptian J. Desert Res., 66, No. 1, 57-68 (2016) 
GC-mass analysis, a TRACE GC Ultra Gas Chromatographs (THERMO Scientific Corp., USA), coupled with a THERMO mass spectrometer detector (ISQ Single Quadrupole Mass Spectrometer).

Yield of foliage leaves cut per plant and per feddan is presented in table (3). The data on the vegetative growth characteristics and chemical compounds were subjected to statistical analysis of variance, and means were compared using the L.S.D. at $5 \%$, as described by Steel and Torrie (1980).

\section{RESULTS AND DISCUSSION}

\section{Growth Parameters}

\subsection{Effect of compost manure}

The results recorded in the two seasons (Tables 1-3) showed that, the application of compost manure fertilizer with $20 \mathrm{~m}^{3} /$ feddan had a significant effect on the different growth characteristics; plant height, number of branches, weight of 1000 seeds $(\mathrm{g})$, weight of seeds/plant $(\mathrm{g})$ and yield of seeds $(\mathrm{kg} / \mathrm{feddan})$ compared to add $10 \mathrm{~m}^{3} /$ feddan. Similar promotion of growth as result of compost manure was reported by Hendawy and Khalid (2011) on Chamomile, Rajesh et al. (2015) on Coriandrum sativum and Khalid et al. (2015) on Foeniculum vulgare. The favorable effect of the compost manure treatments on growth parameter could be explained by its important role in improving soil productivity fertility and thus yield and quality of crops. Compost may increase the availability and concentration of $\mathrm{N}$ and $\mathrm{Ca}$ in soil and as a result increase plant uptake of these elements. Moreover, compost cause decreasing in $\mathrm{pH}$ in plant rhizosphere, which might increase the availability of macro and micro nutrient. Also, compost increases water-holding capacity of the soil (Al-Rashady, 1987; Hasan, 1995 and Sradnick et al., 2013).

\subsection{Effect of cutting}

The data presented in tables (1-3) showed that in both seasons, leaves cutting (one or two cuttings) reduced the plant height significantly as compared to no cutting. Coriandrum sativum plants without cutting gave the highest mean values for plant height $(90.67$ and $83.00 \mathrm{~cm})$ in both seasons, followed by one cutting $(61.84$ and $73.00 \mathrm{~cm})$, while the least values were obtained by cutting the plants twice. On the other hand, one cutting recorded the highest number of branches (45.67 and 47.00), weight of 1000 seeds $(15.55$ and $14.59 \mathrm{~g})$, seeds/plant $(9.92$ and $9.81 \mathrm{~g})$ and yield of seed (352.5 and $348.8 \mathrm{~kg} /$ feddan). These results suggested that, one cutting improves all the growth parameters, except plant height. Similar results were obtained by Thakral et al. (1992), Tehlan and Thakral (2008) and Moniruzzaman and Rahman (2015) on the same plant. 


\subsection{Effect of interaction between compost and cutting}

Regarding the interaction between the effects of compost manure and number of cuttings, data recorded on growth parameters of Coriandrum sativum plants (Tables 4-6) showed that, the highest values with different growth parameters were obtained from plants received $20 \mathrm{~m}^{3}$ compost manure and cutting one in both seasons.

Table (4). Effect of compost and number of cuttings on plant height and number of branches of Coriandrum sativum $\mathrm{L}$.

\begin{tabular}{|c|c|c|c|c|c|c|c|c|c|c|c|c|}
\hline \multicolumn{7}{|c|}{ Plant height (cm) } & \multicolumn{6}{|c|}{ Number of branches/plant } \\
\hline \multirow{2}{*}{$\underbrace{\text { Treatment }}_{\text {Cut }}$} & \multicolumn{3}{|c|}{ First season } & \multicolumn{3}{|c|}{ Second season } & \multicolumn{3}{|c|}{ First season } & \multicolumn{3}{|c|}{ Second season } \\
\hline & 10 & 20 & Mean & 10 & 20 & Mean & 10 & 20 & Mean & 10 & 20 & Mean \\
\hline Without & 88.00 & 93.33 & 90.67 & 75.67 & 90.33 & 83.00 & 38.00 & 44.67 & 41.34 & 39.00 & 47.00 & 43.00 \\
\hline Cut 1 & 56.67 & 67.00 & 61.84 & 65.67 & 80.33 & 73.00 & 44.00 & 47.33 & 45.67 & 45.00 & 49.00 & 47.00 \\
\hline Cut 2 & 24.00 & 42.33 & 33.17 & 38.00 & 42.00 & 40.00 & 19.00 & 22.67 & 20.84 & 20.00 & 24.67 & 22.34 \\
\hline Mean & 56.22 & 67.55 & & 59.78 & 70.89 & & 33.67 & 38.22 & & 34.67 & 40.22 & \\
\hline $\begin{array}{c}\text { L.S.D. at } \\
5 \%\end{array}$ & $\begin{array}{c}\text { Com. } \\
\text { Cut } \\
\text { Com*cut }\end{array}$ & $\begin{array}{l}4.14 \\
3.26 \\
4.43 \\
\end{array}$ & & $\begin{array}{l}4.78 \\
2.01 \\
2.72\end{array}$ & & & $\begin{array}{l}3.13 \\
1.70 \\
2.31\end{array}$ & & & $\begin{array}{l}0.82 \\
1.82 \\
2.44\end{array}$ & & \\
\hline
\end{tabular}

Table (5). Effect of compost and number of cuttings on weight of 1000 seeds ( $\mathrm{g}$ ) of Coriandrum sativum $\mathrm{L}$.

\begin{tabular}{|c|c|c|c|c|c|c|}
\hline \multicolumn{7}{|c|}{ Weight of 1000 seeds $(\mathrm{g})$} \\
\hline \multirow{2}{*}{$\underbrace{\text { Treatment }}_{\text {Cut }}$} & \multicolumn{3}{|c|}{ First season } & \multicolumn{3}{|c|}{ Second season } \\
\hline & 10 & 20 & Mean & 10 & 20 & Mean \\
\hline Without & 13.44 & 14.73 & 14.09 & 10.83 & 12.85 & 11.84 \\
\hline Cut 1 & 15.20 & 15.89 & 15.55 & 13.36 & 15.81 & 14.59 \\
\hline Cut 2 & 9.76 & 10.85 & 10.31 & 10.74 & 10.87 & 10.81 \\
\hline Mean & 12.80 & 13.82 & & 11.64 & 13.18 & \\
\hline L.S.D. at & Com. & 0.26 & & 0.24 & & \\
\hline $5 \%$ & Cut & 0.16 & & 0.15 & & \\
\hline & Com*cut & 0.22 & & 0.21 & & \\
\hline
\end{tabular}

Table (6). Effect of compost and number of cuttings on weight of seeds/plant and yield of seeds of Coriandrum sativum $\mathrm{L}$.

\begin{tabular}{|c|c|c|c|c|c|c|c|c|c|c|c|c|}
\hline \multicolumn{7}{|c|}{ Seeds/plant (g) } & \multicolumn{6}{|c|}{ Yield of seeds (kg/feddan) } \\
\hline Treatment & \multicolumn{3}{|c|}{ First season } & \multicolumn{3}{|c|}{ Second season } & \multicolumn{3}{|c|}{ First season } & \multicolumn{3}{|c|}{ Second season } \\
\hline Cut Compost & 10 & 20 & Mean & 10 & 20 & Mean & 10 & 20 & Mean & 10 & 20 & Mean \\
\hline Without & 7.81 & 11.39 & 9.60 & 7.68 & 11.31 & 9.50 & 277.50 & 404.83 & 341.16 & 272.93 & 402.20 & 337.56 \\
\hline Cut 1 & 7.84 & 11.99 & 9.92 & 7.74 & 11.88 & 9.81 & 278.60 & 426.37 & 352.48 & 275.03 & 422.47 & 348.75 \\
\hline Cut 2 & 2.12 & 2.76 & 2.44 & 2.17 & 2.74 & 2.46 & 75.49 & 98.13 & 86.81 & 76.60 & 97.53 & 87.10 \\
\hline Mean & 5.92 & 8.71 & & 5.86 & 8.64 & & 210.53 & 309.78 & & 208.19 & 307.40 & \\
\hline & Com. & 0.20 & & 0.17 & & & 7.16 & & & 6.51 & & \\
\hline L.S.D. at $5 \%$ & Cut & 0.09 & & 0.11 & & & 3.45 & & & 3.63 & & \\
\hline & Com*cut & 0.13 & & 0.14 & & & 4.68 & & & 4.93 & & \\
\hline
\end{tabular}




\subsection{Essential oil percentage and oil yield (L/feddan)}

Data in table (7), show that essential oil percentage and oil yield (L/feddan) was significantly increased by using compost at $20 \mathrm{~m}^{3} /$ feddan with one cutting during the two seasons. Same results were obtained by Hussein et al. (2010), Darzi and Hadi (2014) and Aćimović et al. (2015).

Table (7). Effect of compost and number of cuttings on essential oil percentage and oil yield of Coriandrum sativum $\mathrm{L}$.

\section{Essential oil (\%)}

\begin{tabular}{|c|c|c|c|c|c|c|c|c|c|c|c|c|}
\hline \multicolumn{7}{|c|}{ Essential oil (\%) } & \multicolumn{6}{|c|}{ Oil yield (L/feddan) } \\
\hline Treatment & \multicolumn{3}{|c|}{ First season } & \multicolumn{3}{|c|}{ Second season } & \multicolumn{3}{|c|}{ First season } & \multicolumn{3}{|c|}{ Second season } \\
\hline $\begin{array}{l}\text { Cempost } \\
\text { Cut }\end{array}$ & 10 & 20 & Mean & 10 & 20 & Mean & 10 & 20 & Mean & 10 & 20 & Mean \\
\hline Without & 0.15 & 0.27 & 0.21 & 0.16 & 0.25 & 0.21 & 0.42 & 1.09 & 0.76 & 0.43 & 1.01 & 0.72 \\
\hline Cut 1 & 0.20 & 0.28 & 0.24 & 0.22 & 0.27 & 0.25 & 0.56 & 1.09 & 0.83 & 0.61 & 1.14 & 0.88 \\
\hline Cut 2 & 0.14 & 0.18 & 0.16 & 0.16 & 0.19 & 0.18 & 0.11 & 0.18 & 0.15 & 0.12 & 0.19 & 0.16 \\
\hline mean & 0.16 & 0.24 & & 0.18 & 0.24 & & 0.36 & 0.79 & & 0.39 & 0.78 & \\
\hline L.S.D. at & Com. & 0.14 & & 0.01 & & & 0.35 & & & 0.01 & & \\
\hline $5 \%$ & Cut & 0.01 & & 0.01 & & & 0.23 & & & 0.01 & & \\
\hline & Com*cut & 0.04 & & 0.02 & & & 0.03 & & & 0.04 & & \\
\hline
\end{tabular}

\section{Chemical Composition}

\subsection{Total nitrogen and carbohydrate percentage}

The uptake and utilization of nitrogen by Coriandrum sativum were affected by both compost manure and number of cuttings (Table 8). In both seasons, treated plants with high level of compost and one cutting gave the best $\mathrm{N}$ contents than other treatments. Similar result were obtained by Mugendi et al. (1999), showing that, application of manure combination with inorganic fertilizer enhanced herbage and $\mathrm{N}$ content with increase the rate of decomposition and mineralization.

Carbohydrate content showed the same trend of nitrogen as shown in table (8). The highest values of carbohydrate percentage were obtained by the application of $20 \mathrm{~m}^{3}$ compost and one cutting. Improvement in vegetative growth characters by the application of high doses of compost may have resulted in stimulation of the photosynthesis, which accumulated more carbohydrate content. As reported by Abdelaziz et al. (2007) on Rosmarinus officinalis, Richards (1993) and Duru and Ducrocq (2000), it was found that, increasing growth parameters by frequencies cuttings may explain the accumulation in carbohydrate. 
Table (8). Effect of compost and number of cutting treatments on nitrogen (\%) and carbohydrate (\%) of Coriandrum sativum L.

\begin{tabular}{|c|c|c|c|c|c|c|c|c|c|c|c|c|}
\hline \multicolumn{7}{|c|}{ Nitrogen (\%) } & \multicolumn{6}{|c|}{ Carbohydrate (\%) } \\
\hline Treatment & \multicolumn{3}{|c|}{ First season } & \multicolumn{3}{|c|}{ Second season } & \multicolumn{3}{|c|}{ First season } & \multicolumn{3}{|c|}{ Second season } \\
\hline $\begin{array}{l}\text { Compost } \\
\text { Cut }\end{array}$ & 10 & 20 & Mean & 10 & 20 & Mean & 10 & 20 & Mean & 10 & 20 & Mean \\
\hline Without & 2.41 & 3.52 & 2.97 & 2.67 & 3.43 & 3.05 & 17.83 & 21.05 & 19. & 19.74 & 22.80 & 21.27 \\
\hline Cut 1 & 2.67 & 3.64 & 3.16 & 2.67 & 3.67 & 3.17 & 18.22 & 22.81 & 20.52 & 22.08 & 23.80 & 22.94 \\
\hline Cut 2 & 2.31 & 3.09 & 2.70 & 2.41 & 3.16 & 2.79 & 17.55 & 19.71 & 18.63 & 18.89 & 23.11 & 21.00 \\
\hline mean & 2.46 & 3.42 & & 2.58 & 3.42 & & 17.87 & 21.19 & & 20.24 & 23.24 & \\
\hline L.S.D. at & Com. & 0.04 & & 0.01 & & & 4.26 & & & 0.35 & & \\
\hline $5 \%$ & Cut & 0.02 & & 0.03 & & & 0.47 & & & 0.57 & & \\
\hline & Com*cut & 2.62 & & 2.02 & & & 0.63 & & & 0.77 & & \\
\hline
\end{tabular}

\subsection{Oil compostion}

The composition of the essential oil with $20 \mathrm{~m}^{3}$ of compost and without cutting or one cutting is presented in tables (9 and 10). A total 28 compound were detected in essential oil. The main constituents of Coriandrum sativum are presented in table (9) it showed that, L-Linalool, terpinene, $\alpha$-Pinene, Camphor, Geraniol, Geranyl acetate, D-Limonene and p-Cymene. The highest percentage of main component was obtained by one cutting of plant compared without cutting under the same level compost. Except, the highest value of p-Cymene was resulted without cutting plants. Same results were obtained by Hussein et al. (2010). Darzi and Hadi (2014) reported that, compost manure application through increase of mineral uptake such as nitrogen and phosphorus has a positive effect on proper biomass production and subsequently the enhanced essential oil content in seed.

Table (9). Effect of compost and number of cuttings on oil GC-mass main compounds of Coriandrum sativum L.

\begin{tabular}{ccccc}
\hline No. & Compound & $\begin{array}{c}\mathbf{2} \text { com. } \\
\text { without } \\
\text { cut \% }\end{array}$ & Compound & $\begin{array}{c}\mathbf{2 ~ c o m . ~} \\
\mathbf{1} \text { cut } \\
\text { \% }\end{array}$ \\
\hline 1 & $\alpha$-Pinene & 2.93 & $\alpha-$-Pinene & 4.27 \\
2 & p-Cymene & 23.58 & p-Cymene & 2.29 \\
3 & D-Limonene & 0.81 & D-Limonene & 1.98 \\
4 & Terpinene & 3.68 & Terpinene & 7.83 \\
5 & L-Linalool & 46.80 & L-Linalool & 62.64 \\
6 & Camphor & 3.92 & Camphor & 5.97 \\
7 & 1-Borneol & 0.23 & 1-Borneol & 0.30 \\
8 & Geraniol & 1.30 & Geraniol & 3.59 \\
9 & Geranyl acetate & 1.81 & Geranyl acetate & 5.30 \\
\hline
\end{tabular}

Egyptian J. Desert Res., 66, No. 1, 57-68 (2016) 
Table (10). Effect of compost and number of cuttings on oil GC-mass trace compounds of Coriandrum sativum L.

\begin{tabular}{|c|c|c|c|c|}
\hline No. & Compounds & $\begin{array}{c}2 \text { com. } \\
\text { without } \\
\text { cut } \%\end{array}$ & Compounds & $\begin{array}{c}2 \text { com. } \\
1 \text { cut } \\
\%\end{array}$ \\
\hline 10 & Camphene & 0.34 & Camphene & 0.52 \\
\hline 11 & Sabinene & 0.16 & Sabinene & 0.29 \\
\hline 12 & a-Myrcene & 0.28 & a-Myrcene & 0.74 \\
\hline 13 & $\alpha$-Terpinolene & 0.19 & $\alpha$-Terpinolene & 0.05 \\
\hline 14 & $\begin{array}{c}\text { Trans-Sabinene } \\
\text { hydrate }\end{array}$ & 0.84 & $\begin{array}{c}\text { Trans-Sabinene } \\
\text { hydrate }\end{array}$ & 0.18 \\
\hline 15 & 1-terpineol & 0.42 & $\alpha$-Phellandrene & 0.08 \\
\hline 16 & 1-Menthone & 0.44 & 1-Octanol & 0.05 \\
\hline 17 & D-menthone & 0.97 & $\alpha$-Terpinolene & 0.54 \\
\hline 18 & (-) 4-terpineol & 3.63 & 1-4 Terpineol & 0.32 \\
\hline 19 & $\alpha$-Terpineol & 4.21 & $\alpha$-Terpineol & 0.58 \\
\hline 20 & p-Menth-1-en-3-ol & 0.20 & Decanal & 0.60 \\
\hline 21 & $\alpha$-Citronellol & 0.20 & $\alpha$-Citronellol & 0.36 \\
\hline 22 & p-Menth-1-en-3-ol & 0.13 & 2-Decenal & 0.13 \\
\hline 23 & Thymol & 0.14 & 1-Decenol & 0.12 \\
\hline 24 & trans-Caryphyllene & 0.70 & Undecanal & 0.12 \\
\hline 25 & (+) spathulenol & 0.28 & Myrtenyl acetate & 0.15 \\
\hline 26 & Caryphyllene-oxide & 0.51 & Dodecanal & 0.31 \\
\hline 27 & Tau-Cadinol & 0.77 & 2-Dodecanal & 0.32 \\
\hline 28 & $\begin{array}{l}\text { Spiro (4.5) decan-6- } \\
\text { ol,6 methyl }\end{array}$ & 0.55 & $\begin{array}{l}\text { 2-Pentadecanone, } 6 \text {, } \\
\text { 10, 14-trimethyl }\end{array}$ & 0.10 \\
\hline
\end{tabular}

\section{CONCLUSION}

From the above mentioned results, it could be concluded that, application of compost manure at $20 \mathrm{~m}^{3} /$ feddan and cutting Coriandrum sativum plant at 45 days after sowing give the highest growth parameters and chemical content.

\section{REFERENCES}

Abdelaziz, M., R. Pokluda and M. Abdelwahab (2007). Influence of compost, microorganisms and NPK fertilizer upon growth, chemical composition and essential oil production of Rosmarinus officinalis $\mathrm{L}$. Not. Bot. Hort. Agrobot. Cluj., 35 ( 1): 86-90.

Aćimović, M.G., Ž.K. Dolijanović, S.I. Oljača, D.D. Kovačević and M.V. Oljača (2015). Effect of organic and mineral fertilizers on essential oil contentment in Caraway, Anise and Coriander fruits. Acta Sci. Pol., Hortorum Cultus, 14 (1): 95-103. 
Allison, F.E. (1973). In "Soil Organic Matter and its Role in Crop Production", Elsevier, New York, 637 pp.

Al-Rashady, R.K. (1987). In "Plant Soil Relationships". High Education and Scientifc Research Ministry. Basra Univ., Iraq. 464 pp.

Chaplin, M.F. and J.F. Kennedy (1994). In "Carbohydrate Analysis, A Practical Approach". Published in the U.S.A. by Oxford Univ. Press. $31 \mathrm{pp}$.

Darzi,T.M. and M.R.H.S. Hadi (2014). Response of concentration and composition of essential oil of Coriander (Coriandrum sativum L.) to cattle manure and nitrogen fixing bacteria. Ethno-Pharmaceutical Products, 1 (2): 35-42.

Duru, M. and H. Ducrocq (2000). Growth and senescence of the successive leaves on a Cocksfoot Tiller effect of nitrogen and cutting regime. Annals of Botany, 85: 645-653.

Emamghoreishi, M., M. Khasaki and M.F. Aazam (2005). Coriandrum sativum evaluation of its anxiolytic effect in the elevated plus-maze. Journal of Ethnopharmacology, 96: 365-370.

Hasan, A.A. (1995). In "Principles of Physiology for Plant Genetic Improvement". The Academic Library. Cairo, Egypt, 328 pp.

Hendawy, S.F. and K.A. Khalid (2011). Effect of chemical and organic fertilizers on yield and essential oil of Chamomile flower heads. Medicinal and Aromatic Plant Sci. and Biotechnology, 5(1): 43-48.

Hussein, A.H., S. Al Ahl and A.K. Khalid (2010). Response of Coriandrum sativum L. essential oil to organic fertilizers. Journal of Essential OilBearing Plants Jeobp, 13 (1): 37-44.

James, C.S. (1995). In "Analytical Chemistry of Food". Blackie Academic and Professional Publisher, An Imperin of Chapman and Hall, 178 pp.

Khalid, K.A., E.A. Omer. A.G. El Gendy and M.S. Hussein (2015). Impact of organic compost and humic acid on essential oil composition of sweet fennel (Foeniculum vulgare var. Dulce) under sandy soil conditions in Egypt. World J. Pharm. Sci., 3(2): 160-166.

Moniruzzaman, M. and M.M. Rahman (2015). Effect of nitrogen level and leaf cutting frequency on foliage and seed yields of Coriander. Bangladesh J. Agril. Res., 40 (1): 53-60.

Moslemi, M., A. Aboutalebi, H. Hasanzade and M.H. Farahi (2012). Evaluation of the effects of different levels of vermin-compost on yield and yield components of Coriander (Coriandrum sativum L.). Ann. Bio. Res., 3: 4852-4853.

Mugendi, D.N., P.K.R. Nair, J.N. Mugwe, M.K. O’Neill, M.J. Swift and P. Woomer (1999). Alley cropping of maize with Calliandra and Leucaena in the Subhumidhighlands of Kenya. Part 2: Biomass decomposition, $\mathrm{N}$ mineralization, and $\mathrm{N}$ uptake by Maize. Agroforestry Syst., 46: 51-64.

Egyptian J. Desert Res., 66, No. 1, 57-68 (2016) 
Osman, Y.A.H. (2000). Possibility of production of Coriander (Coriandrum sativum L.) under Sinai conditions. Ph.D. Thesis, Fac. Agric., Cairo Univ., Egypt.

Rajesh, K., M.K. Singh, K. Vijay, R.K. Verma, J.K. Kushwah and P. Mahender (2015). Effect of nutrient supplementation through organic sources on growth, yield and quality of Coriander (Coriandrum sativum L.). Indian J. Agric. Res., 49 (3): 278-281.

Richards, J.H. (1993). Physiology of plant recovering from defoliation. Proceedings of the XVII, International Grassland Congress, New Zealand, 85-94.

Singh, K. (1976). In”Manorial Requirement of Vegetable Crops”. Icar, New Delhi.

Sradnick, A., R. Murugan, M. Oltmanns, J. Raupp and R.G. Joergansen (2013). Changes in functional diversity of the soil microbial community in a heterogeneous sandy soil after long-term fertilization with cattle manure and mineral fertilizer. Applied Soil Ecology, 63: 23-28.

Steel R.G. and S.H. Torrie (1980). In "Principles and Procedures of Statistics". Second Edition, McGraw-Hill Inc.

Tehlan, S.K. and K.K. Thakral (2008). Effect of different levels of nitrogen and leaf and seed yield of Coriander (Coriandrum sativum). Journal of Spices and Aromatic Crops, 17 (2): 180-182.

Thakral, K.K., G.R. Singh, U.C. Pandey and V.K. Srivastava (1992). Effect of nitrogen levels and cuttings on the production of green leaves and seed yield of coriander cv. Narnaul Selection. Haryana Agril. Univ. J. Res., 22 (1): 35-39.

Tiwari, R.S., S. Ankur Agarwal, C. Sengar and A. Agarwal (2002). Effect of dates of sowing and number of cuttings on growth, seed yield and economics of coriander cv. Pant Haritima. Crop Res. Hisar., 23 (2): 324-329.

Received: $14 / 6 / 2016$

Accepted: 3/10/2016 
تأثير الكومبست وعدد مرات الحش على إنتاجية نبات الكسبرة تحت ظروف وليد عمح عبا العظيم قسم النباتات الطبية والعطرية، مركز العزيم بحوث الصحر اء، المطرية، القاهرة، مصر

أجريت تجربتين حقليتين بمحطة بحوث المغارة بوسط سيناء و التابعة لمركز بحوث إثاث

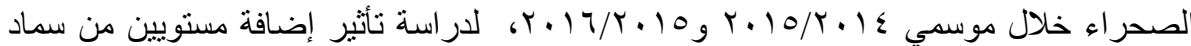

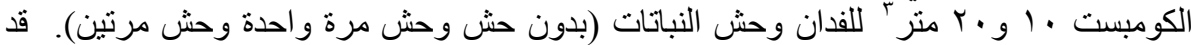

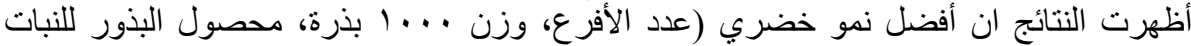

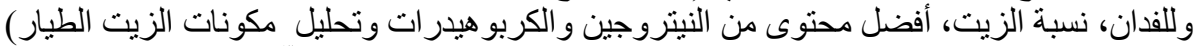

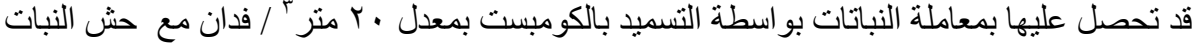

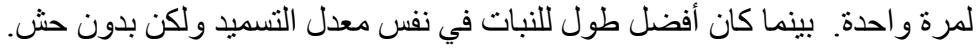

Egyptian J. Desert Res., 66, No. 1, 57-68 (2016) 